UDC 37.014 .543

DOI 10.21272/mmi.2018.2-18
JEL Classification: A13, A20, C13, C51, F01, H52, 122

Anna Vorontsova, Ph.D., International Economic Relations Department, Sumy State University,

Sumy, Ukraine

Serhiy Lyeonov, D.Sc., Professor, Economic Cybernetics Department,

Sumy State University, Sumy, Ukraine

Tetiana Vasylieva, D.Sc., Professor, Finance and Entrepreneurship Department,

Sumy State University, Sumy, Ukraine

Artem Artyukhov, Ph.D., Associate Professor, Head of the Group of Strengthening Academic Integrity,

Sumy State University, Sumy, Ukraine

\title{
INNOVATIONS IN THE FINANCING OF LIFELONG LEARNING SYSTEM: EXPENDITURE OPTIMIZATION MODEL
}

In recent years, in most countries of the world, it is observed the spread and change of the main paradigm of the education system, which involves the addition of classical formal education (in official educational institutions with the official document about a degree) with informal and informal types. The last two forms of education are the acquisition of knowledge, skills and abilities for comprehensive development and qualification development of a person, the formation of a civic position and the motivation for self-development and self-education, which is not necessarily accompanied by officially recognized documents but has no less value. This leads to the formation of a new system of learning that will operate throughout the life of a person and should become one of the strategic objectives for any state that strives for sustainable development. Such changes require an innovative approach at all stages of the new system formation, including its financial support. However, due to objective reasons for the limited budget funds, the state cannot independently provide financing for the lifelong learning system without involving additional economic entities. Thus, this article is devoted to building expenditure optimization model as the main innovation in the financing of the lifelong learning system. For this purpose, the authors define the stage of formation, the essence and basic characteristics of the lifelong learning system in the modern world. The next step was a providing of a comparative analysis of the main trends in financing education in the countries of the Organization for Economic Cooperation and Development (OECD) and their partners and Ukraine at the expense of various sources (public and private) and for different levels of education (primary education, secondary education, postgraduate education, elementary education higher education, higher education). On the results of analysing the absence of structured information about extrabudgetary funding of lifelong learning system is indicated. Thus, authors developed the approach to estimating potential volume of extra-budgetary sources of funding for a lifelong education system by using structured equation modelling method, where the informational basis are education expenditures of the Consolidated Budget of Ukraine and the Education Index (as a component of the Human Development Index). For calculations software, STATISTICA 6.1 was used. This approach allows to indicate the expenditure optimization model and to determine the financial potential of the lifelong learning system development.

Keywords: financial support, lifelong learning system, public expenses, private expenses, expenses optimization model, structured modelling. 
Introduction. The development of the education sector has always been and remains one of the strategic objectives for any state that seeks to ensure sustainable development, a competitive and innovative economy, a decent standard of living for its people. However, in the conditions of the dynamic transformations of the foreign and domestic economic and social systems, the rapid development of information technology and scientific-technological progress, there is a need to change the conceptual approach to understanding the essence of the education system in the direction of its length throughout human life. In this regard, the basic approaches to financing a lifelong learning system (LLS) are modified. Education costs start to be seen as investments in human and social capital, educational innovations, which contributes to the growth of positive externalities in the socio-economic field. However, the state cannot independently provide funding for the LLS without involving additional economic entities (such as business, householders, non-government organizations and so on).

Recent research and publications analysis. The theoretical foundations of lifelong learning concept have been developed in studies of such scholars as Aspin D. N., Chapman J.D. (Aspin D. N., Chapman J. D., 2000), Collins J. (Collins J., 2009), Dave R. H. (Dave R. H., 1976), Duyff R. L. (Duyff R. L., 1999), Laal M. (Laal M., 2011), Shevchenko L. S. (Shevchenko L. S., 2013) and so on. In the work of Ishchenko-Padukova, O., Kazachanskaya, E., Movchan, I., \& Nawrot, L. (Ishchenko-Padukova O., Kazachanskaya E., Movchan, I., Nawrot L., 2017) was confirmed the importance of education for economy on the national and global levels and the need appropriate of legal regulation, Tvaronavičienè $M$., Tarkhanova E., Durglishvili N. (Tvaronavičienè M., Tarkhanova E., Durglishvili N., 2018) explored how educational systems might increase the economic, innovative and business potential of the regional centers and contribute to the sustainable economic development

The different sides of educational innovations in the LLS were studied by Skačkauskienè I., Kazlauskienė E., Katinienè A. (Skačkauskienè I., Kazlauskienė E., Katinienė A., 2017), Vardanyan N. (Vardanyan N., 2017), Bagmet M., Liakhovets O. (Bagmet M., Liakhovets O., 2017), Švagždienė, B., Jasinskas, E., Simanavičius A. (Švagždienè B., Jasinskas E., Simanavičius A., 2017), Szilágyi,G. A. (Szilágyi G. A., 2017) discovered a forms of knowledge sharing networks, Vasilyeva, T., Lyeonov, S., Adamičková, I., Bagmet, K. (Vasilyeva T., Lyeonov S., Adamičková I., Bagmet K., 2018) proposed their own methodology of assessing institutional quality of the social (and educational) sector.

In particular, this article is a continuation of our study in the sphere of LLS. In our previous works we discovered the optimal sources of educational services financing in the sphere of preferences of economic agents through the prism of the theory of public and private goods (Vasylieva T., Lyeonov S., Vorontsova A., 2018), proved the importance of LLS financing for the social and economic development of the country through correlation-regression analysis tools (Petrushenko Yu. M., Vasylieva T. A., Lyeonov S. V., Vorontsova A. S., 2017), measured the effectiveness of the existing financial support of the LLS in of Ukraine through stochastic frontier analysis (Jikia G., Vorontsova A., Petrushenko Y., 2017) and so on.

Despite the fact that there are a lot of studies about the lifelong learning system in the context of educational innovations, the problem of building a lifelong learning system expenses optimization model requires further development.

Thus, the research goal of the paper is to build optimization model as the main innovation in the financing of the lifelong learning system with the use of structured equation modelling (SEM).

The paper is organized as follows. Section 1 is devoted to the theoretical background and the studies concerning the lifelong learning concept in the context of the economic transition to a sustainable growth model. Section 2 introduces the results of comparative analysis of the financial provision of an education system in the OECD countries and their partners plus Ukraine. Section 3 presented the results of building lifelong learning system expenses optimization model as the optimal ratio between budget and extrabudgetary expenditures on education. Conclusions summarize the research and contain some recommendations for theory, practice, and future research on the topic. 
A. Vorontsova, S. Lyeonov, T. Vasylieva, A. Artyukhov. Innovations In The Financing Of Lifelong Learning System: Expenditure Optimization Model

Research results. Literature Review of Lifelong Learning Concept. The lifelong learning concept goes back to 60-70-ies of the twentieth century, which is associated with the development of adult education. However, this paradigm was more widely disseminated in the 1970s, when UNESCO adopted lifelong learning as one of its own principles for reforming education in the world. In addition, the concept of lifelong learning has become widespread thanks to the joint efforts of international organizations such as the Council of Europe, the Organization for Economic Co-operation and Development (OECD), the World Bank, etc.

Significant contribution to the development of the lifelong learning concept was made by R. H. Dave, who believed that lifelong learning is the process of personal, social and professional development of an individual throughout his/her life, with the aim of improving the quality of life of both the individual and the society (Dave R. H., 1976). In his work, he highlighted 21 principles of lifelong learning, among which we distinguish the following:

- a possibility of creating alternative structures to get an education;

- emphasis on guided self-education;

- emphasis on self-education, self-training, self-assessment;

- learning in different social groups (family, society);

- development of the training and educational society, to learn "to be", "to become" someone (Dave R. H., 1976).

In addition, lifelong learning was studied by many scholars like R. L. Duyff (1999), D. N. Aspin and J. D. Chapman (2000), J. Collins (2009), etc.

The main features of LLS include the following:

- opportunity to acquire lifelong learning in order to improve knowledge, skills and competence, and most importantly, to have the prospect of employment (Shevcheko L., 2013);

- transition from a linear step-by-step form of education to a multidimensional one, which allows being engaged in both personal development (informal education) and additional vocational one;

- broad branch structure of education and availability of its various forms.

- Regarding the forms of LLS, they include:

- formal or academic, under which we understand officially recognized educational programs (school, vocational, higher) which are taught in educational institutions and for which the corresponding diplomas, certificates or other supporting documents are issued;

- informal, which is not officially recognized at the level of educational institutions, for which there is no temporal or spatial framework, it exists for personal or professional development, personal growth, improvement of the quality of life, etc. It is not always confirmed by relevant documents or certificates;

- informational or social, which includes unstructured learning in the family, community, at work, while performing certain tasks, reading, communicating, etc.

The lifelong learning concept closely related to the concept of sustainable development. Goal 4 of the 2030 Agenda for Sustainable Development targets to ensure inclusive and quality education for all and promote lifelong learning" (UN General Assembly, 2015). Also, education interrelated with other sustainable development goals in the context of reducing poverty, gender and other inequalities, increasing labour productivity and green innovations, improving health and reducing birth rate and so on.

Consequently, changing the approach to understanding the structure and functions of the education system requires a change and the peculiarities of its financing throughout human life.

The lifelong learning concept closely related to the concept of sustainable development. Goal 4 of the 2030 Agenda for Sustainable Development targets to ensure inclusive and quality education for all and promote lifelong learning" (UN General Assembly, 2015). Also, education interrelated with other sustainable development goals in the context of reducing poverty, gender and other inequalities, increasing labour productivity and green innovations, improving health and reducing birth rate and so on. 
Consequently, changing the approach to understanding the structure and functions of the education system requires a change and the peculiarities of its financing throughout human life.

Comparative Analysis of the Financial Support of Education. A significant part of our research is based on comparative analysis of financing of the education system in the OECD countries and their partners plus Ukraine and identification of the main trends and possible problems of this process.

The first step of our study is to analyse the total costs of formal education (from primary to tertiary education levels) in 2014 in the OECD countries and their partners plus Ukraine in terms of the main sources of funding - public and private provision (Figure 1).

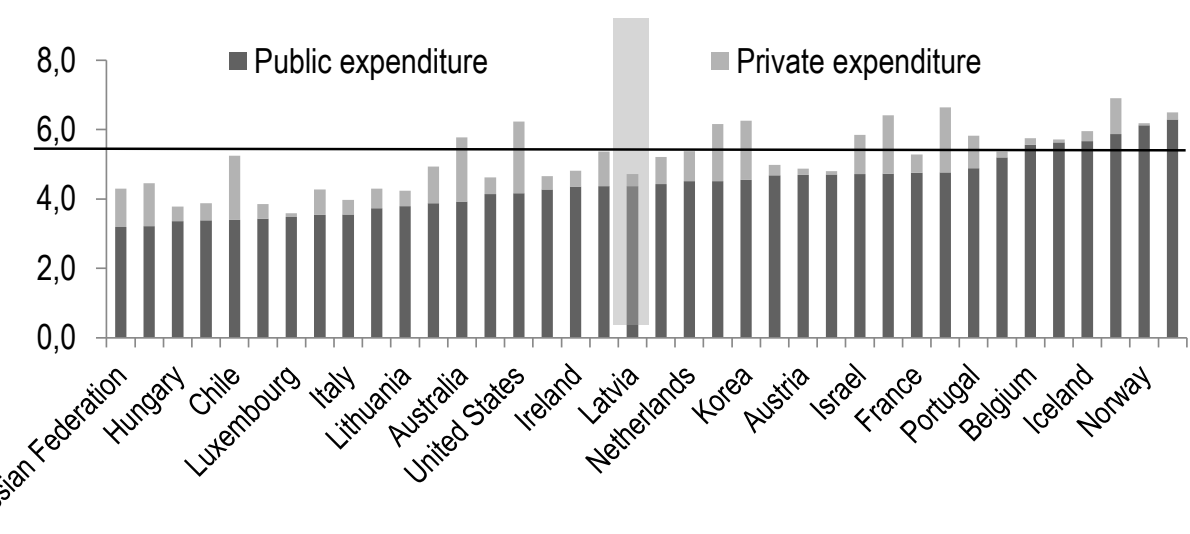

Figure 1 - Public and private expenditures on education in OECD countries and their partners plus Ukraine in 2014, \% of GDP (statistical data OECD, 2017, State Statistics Service of Ukraine National Accounts of Education of Ukraine, 2015)

Let's clarify, that by public expenditure on education we mean direct public funding for educational institutions of different levels from central and local budgets. As OECD experts mention, private expenditure refers to expenditure funded by private sources (households and other private entities) such as tuition fees and other student or household payments to educational institutions and outside institutions (OECD, 2017). In our opinion, the private sources should also include expenses of business entities for vocational training of employees, expenses of NGO for educational activities for the population, etc.

In 2014 OECD countries spent an average of $5.2 \%$ of GDP on education, of which $4.4 \%$ of GDP is public expenditures, $0.8 \%$ of GDP is private expenditures. Ukraine has the largest share of total educational expenditure for all levels of education - $6.9 \%$ of GDP, Great Britain $-6.6 \%$ of GDP and Denmark $-6.5 \%$ of GDP. The lowest education expenditures have Russia - $3.3 \%$ of GDP, Luxembourg $-3.6 \%$ of GDP and Hungary $-3.8 \%$ of GDP.

By the way, the largest share of private expenditures has Australia (1.8\% of GDP), United Kingdom ( $1.9 \%$ of GDP) and United States (2.1\% of GDP), while Norway, Finland and Luxembourg have the lowest share.

It should be noted that for a comparison indicator of a particular country is taken share of GDP, but the possibility of shadowing the economy should be considered (thus, according to various experts estimates for Ukraine this indicator can reach 50\%), which significantly reduces the expenditure indicator as a percentage of GDP.

In order to estimate the total amount of education financing in Ukraine, data of the National Accounts for Education, which are compiled according to the Methodological Provisions on drawing up a subsidiary (satellite) accounts of education in Ukraine, were used. 

Expenditure Optimization Model

Subsidiary account of education is widely recognized in the European statistical practice method of generalizing, describing and analysing the financing of national education systems used to improve their performance. The methodology of compiling the subsidiary account of education has been developed by European statisticians to provide the European Statistical Commission with comparable indicators of financial flows running into this field (National Accounts of Education of Ukraine, 2015).

Having analysed the trends of total expenditures on education, in our opinion, it is practically important to focus on the distribution of financing of the main levels of education in OECD countries and their partners plus Ukraine in 2014. (Figure 2), which includes:

- primary education (which includes pre-primary and primary education);

- secondary education;

- post-secondary (non-tertiary) education, including vocational education;

- tertiary education (in the higher education institutions).

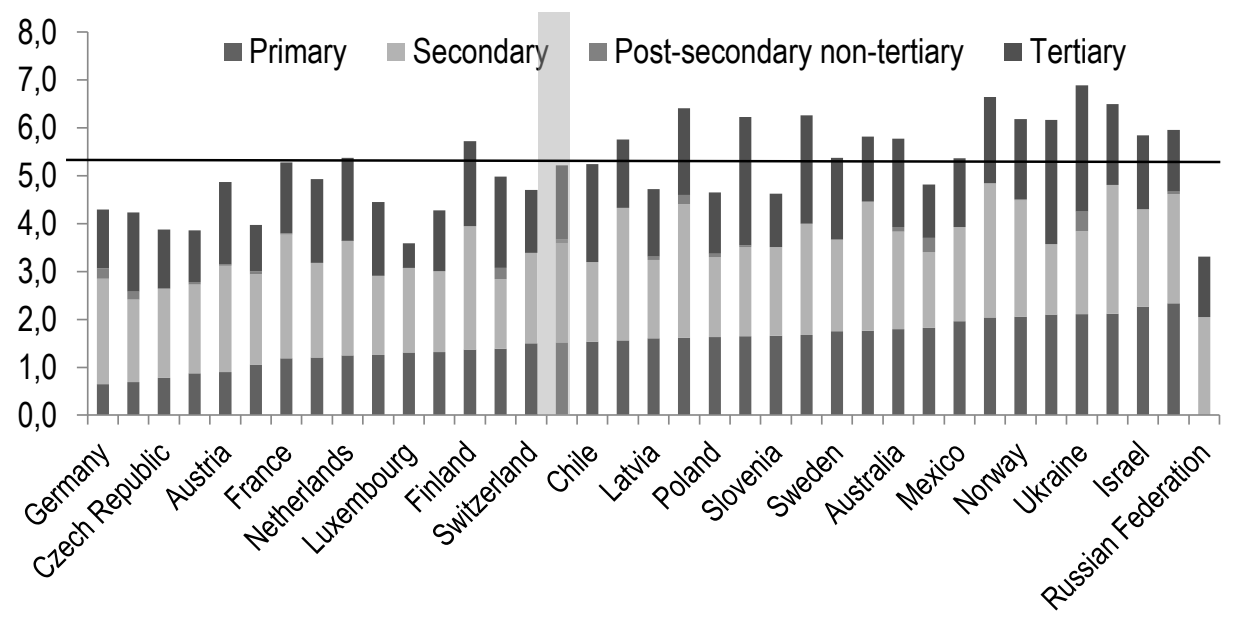

Figure 2 - Expenditures on education by levels of education system in OECD countries and their partners plus Ukraine in 2014, \% of GDP. (statistical data OECD, 2017, State Statistics Service of Ukraine, National Accounts of Education of Ukraine, 2015)

Analysing the above figure, it can be stated that, on average, OECD countries spend $1.5 \%$ of GDP on primary education, $2.1 \%$ of GDP on secondary education, $0.1 \%$ of GDP on post-secondary and $1.5 \%$ of GDP on tertiary education. Moreover, primary education is best funded in Iceland, Israel (approximately $2.3 \%$ of GDP); secondary education is best supported in the UK, New Zealand, Belgium (about $2.8 \%$ of GDP); and tertiary education is most financially provided in Ukraine, Canada and the USA (more than $2.5 \%$ of GDP).

In a more detailed analysis (Figures 3 and 4 ) it becomes clear that, on average, in OECD countries over $90 \%$ of primary, secondary and post-secondary non-tertiary education costs (or $3.74 \%$ of GDP) are funded at the expense of the budget, and in terms of the cost of tertiary education this indicator is on average about $70 \%$ (or $1.1 \%$ of GDP).

Iceland, Norway, Ukraine and Denmark have the highest share of public transfers on primary, secondary and post-secondary non-tertiary education (more than $4.5 \%$ of GDP), while the United Kingdom ( $0.6 \%$ of GDP), Australia ( $0.7 \%$ of GDP) and New Zealand ( $0.8 \%$ of GDP) are leaders in private financing.

Considering the level of tertiary education, the situation is somewhat different. The best indicators as 
the share of public expenditures have Estonia, Finland and Ukraine (more than $1.7 \%$ of GDP), of private expenditures, have United Kingdom, Chile, Canada, United States (more than $1.3 \%$ of GDP).

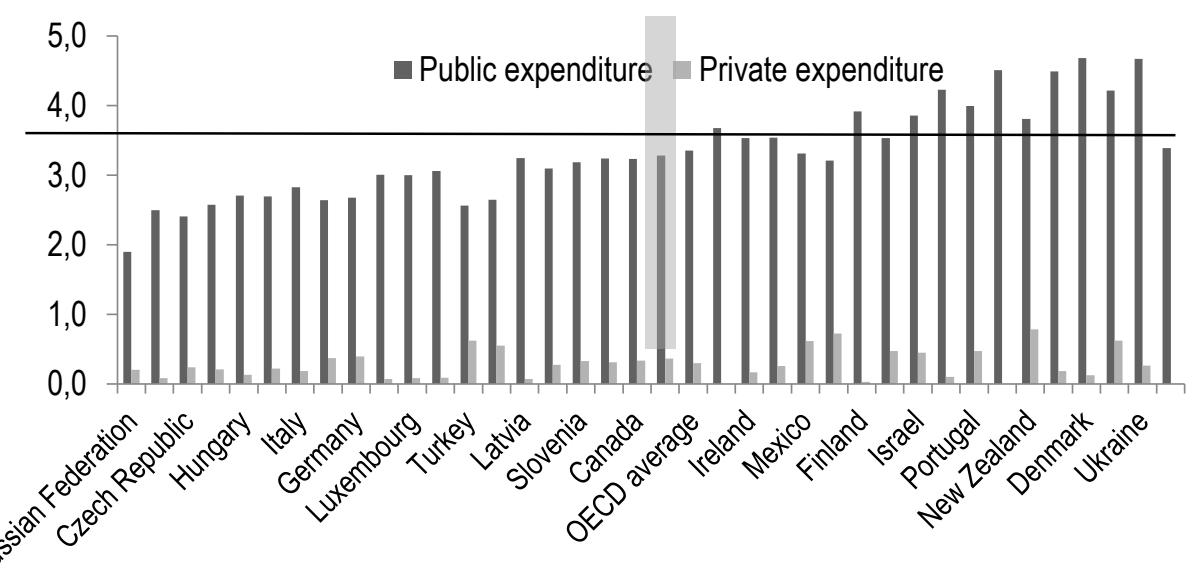

Figure 3 - Expenditures on primary, secondary and post-secondary non-tertiary education by sources of financing in OECD countries and their partners plus Ukraine in 2014, \% of GDP (statistical data OECD, 2017, State Statistics Service of Ukraine National Accounts of Education of Ukraine, 2015)

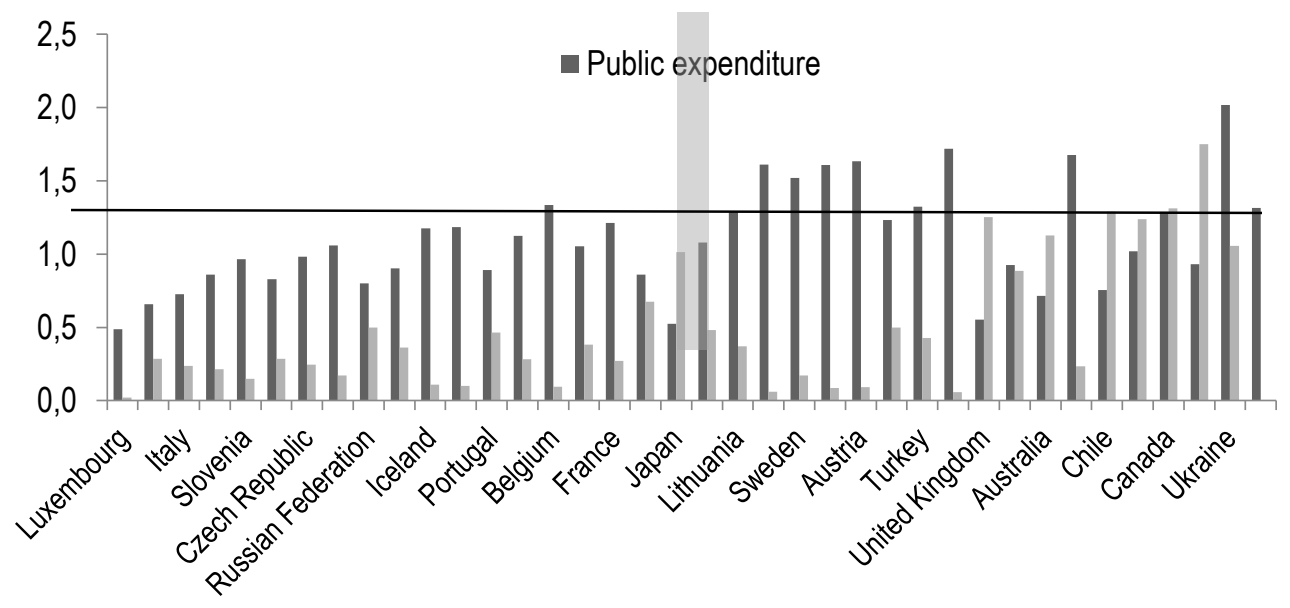

Figure 4 - Expenditures on tertiary education by sources of financing in OECD countries and their partners plus Ukraine in 2014, \% of GDP (statistical data OECD, 2017, State Statistics Service of Ukraine National Accounts of Education of Ukraine, 2015)

For a more detailed understanding of the structure of total expenditures on education, let us consider separately the sources of the financial provision of education in Ukraine in terms of cost and percentage (as \% of GDP) for 2007-2016 (Figure 5), distinguishing the main actors:

- the central government, represented by various ministries and departments, is actually the administrator of the state budget;

- local budgets presented by regional government agencies; 
A. Vorontsova, S. Lyeonov, T. Vasylieva, A. Artyukhov. Innovations In The Financing Of Lifelong Learning System: Expenditure Optimization Model

- the private sector, namely private firms, and corporations;

- householders.

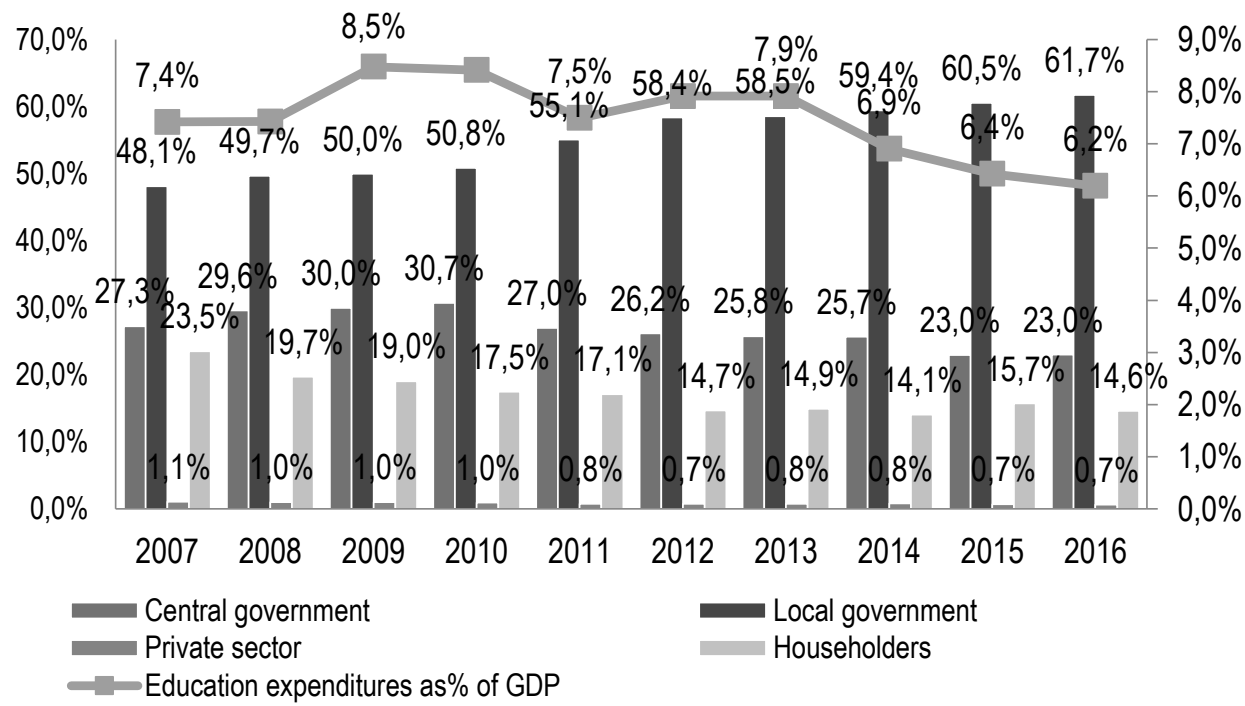

Figure 5 - Changes in Ukraine's total expenditures on education by sources in terms of cost and percentage for 2007-2016 (State Statistics Service of Ukraine National Accounts of Education of Ukraine, 2017-2016)

The main source of financing expenditures for education is the local government, its share for the analysed period increased from $48 \%$ in 2007 to $62 \%$ in 2016 , i.e. by $14 \%$. In our opinion, this is the evidence of the decentralization reform in Ukraine. The central government took the second place in terms of financing education expenditures (20.5\%) in 2016. Householders provide approximately $15 \%$ of financial support for education. It should be noted that their contribution for the analysed period was reduced by approximately $9 \%$. This tendency can be partly explained by a decrease in the birth rate in the respective years, which also affected the number of pupils and students and was the consequence of the financial crisis. Private entrepreneurs provided the smallest financing of education in Ukraine, which was at the level of approximately $1 \%$ over the analysed period. This proves that employers' representatives have little interest in the development of the skilled labour force.

In percentage terms, since 2009 the reduction of GDP expenditures for education by $2.5 \%$ of GDP has been observed, which in 2016 was only $6.2 \%$ of GDP. However, this indicator is rather high compared to other OECD countries that were analysed in Figure 1.

The main source of financing the primary, secondary and post-secondary education in Ukraine is local budgets and on a limited amount household budget. As for tertiary education teaching, it is under the control of the central government by $60 \%$ and households. This is the evidence of a high proportion of students on a contractual form of study. Postgraduate education is financed above all at the expense of households and central government. In addition, in contrast to other components of education, private entities participate in their development by $12 \%$.

Lifelong Learning System Expenses Optimization Model. The conducted comparative analysis allows us to understand the main tendencies in formal education funding while information about financing the non-formal component of LLS is limited. In addition, extra-budgetary financial flows on education in 
most countries with transition economies (including Ukraine) are not systematically registered in statistical bases. This complicates the process of analysing of available costs optimality in LLS and developing recommendations and forecasts for attracting financial resources from different sources, primarily at the expense of the state and non-state sectors.

In this connection, methodical principles for determining lifelong learning system expenses optimization model in the context of the economic transition to a sustainable growth model are proposed. For this purpose, the approach of estimation of potential amounts of extra-budgetary sources of funding for LLS is developed. It is proposed to do by using structured equation modelling (SEM), which corresponds to the real volumes of budget financing and the existing index of education in the country (as a component of human development index). This technique is based on the data of Ukraine, but can also be used for other countries of the world under a similar algorithm. The basis of the structured modeling toolkit is provided, which helps to solve the problem by introducing latent and observed variables, building the relationship between the indicators in the form of a system of equations.

In econometric studies (Kozmenko, O.V., 2014) the SEM can be represented as follows:

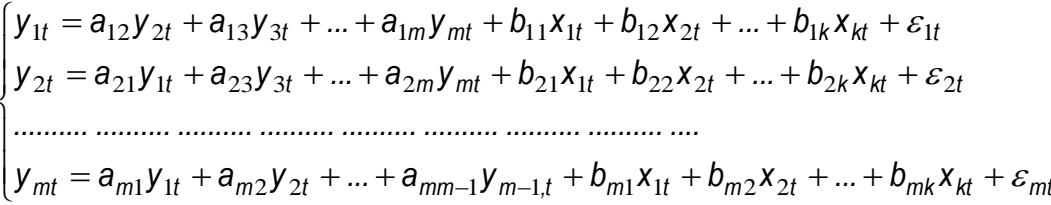

$$
\begin{aligned}
& y_{m t} \text { - endogenous (dependent) variables; } \\
& x_{k t}-\text { exogenous (independent) variables; } \\
& t \text { - observations }(t=1,2, \ldots, n) \text {; } \\
& a_{m m}, b_{m k} \text { - structural coefficients; } \\
& \varepsilon_{m t} \text { - random error term. }
\end{aligned}
$$

As input data for the proposed approach, we select budget expenditures on the education from Consolidated Budget of Ukraine and the index of education (as a component of human development index) for 2002-2016 (Table 1). The selection of the educational component of the human development index is due to the fact that it is an internationally recognized indicator of measuring the standard of living, education, and literacy of population, also it shows the development of human capital. Therefore, the relationship between the index of education and the financing of the education sector from the budget and extra-budgetary sources is indisputable. The calculations were made using the software package Statistica 6.1.

Table 1 - Input data for SEM (compiled by the author based on the statistical data of the State Treasury Service of Ukraine and the World Bank)

\begin{tabular}{|c|c|c|}
\hline Year & Budget expenditures on education, mln. UAH & Index of education \\
\hline 1 & 2 & 3 \\
\hline 2002 & 12269,05 & 0,754 \\
\hline 2003 & 14977,74 & 0,763 \\
\hline 2004 & 18333,18 & 0,771 \\
\hline 2005 & 26801,75 & 0,780 \\
\hline 2006 & 33785,00 & 0,789 \\
\hline 2007 & 44333,58 & 0,790 \\
\hline 2008 & 60959,37 & 0,791 \\
\hline
\end{tabular}


A. Vorontsova, S. Lyeonov, T. Vasylieva, A. Artyukhov. Innovations In The Financing Of Lifelong Learning System: Expenditure Optimization Model

Table 4

\begin{tabular}{|c|c|c|}
\hline 1 & 2 & 3 \\
\hline 2009 & 66773,56 & 0,792 \\
\hline 2010 & 79826,05 & 0,793 \\
\hline 2011 & 86253,55 & 0,794 \\
\hline 2012 & 101560,95 & 0,799 \\
\hline 2013 & 105538,70 & 0,800 \\
\hline 2014 & 100109,53 & 0,803 \\
\hline 2015 & 114188,28 & 0,803 \\
\hline 2016 & 129437,71 & 0,805 \\
\hline
\end{tabular}

According to the algorithm of SEM, in the first step, we map a path diagram that helps us to graphically interpret the model and present the existing relationships between the parameters (Fig. 6).

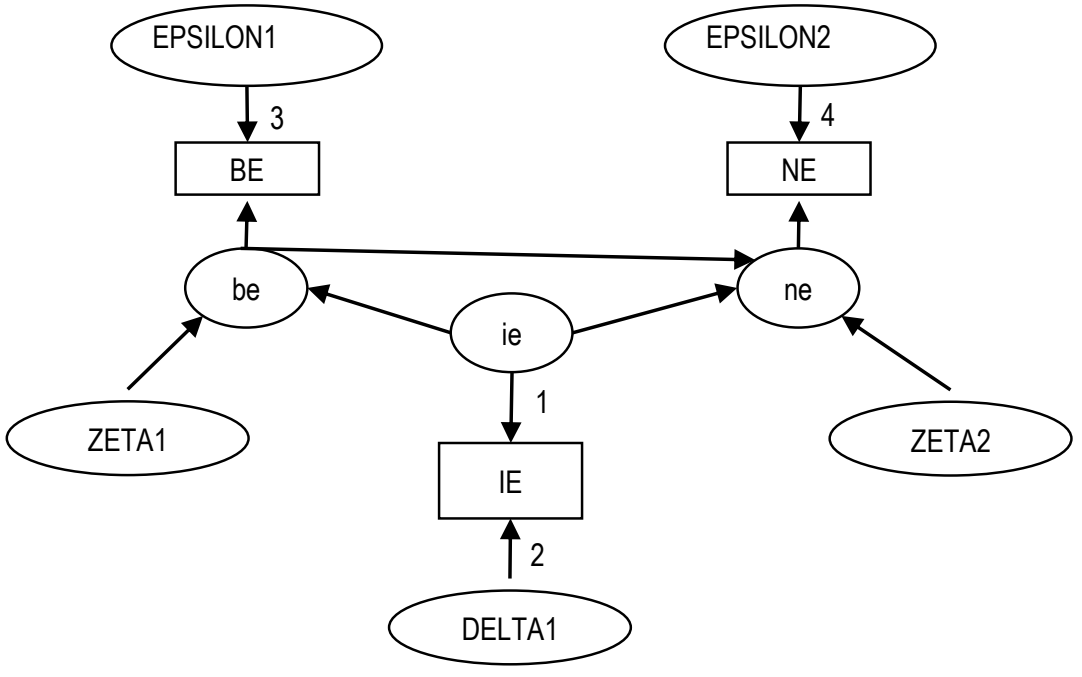

Figure 6 - Path diagram for interconnection of the index of education, budget and extrabudgetary expenditures on education

Note that during the calculations the following parameters were introduced (Table 2).

\section{Table 2 - SEM parameters}

\begin{tabular}{|c|l|}
\hline Parameter & \multicolumn{1}{|c|}{ Explanation } \\
\hline $\mathrm{IE}$ & An observed variable of the index of education (exogenous factor) \\
\hline ie & The latent factor of the index of education (exogenous factor) \\
\hline BE & An observed variable of budget expenditures on education (endogenous factor) \\
\hline be & The latent factor of budget expenditures on education (endogenous factor) \\
\hline NE & $\begin{array}{l}\text { An observed variable of extra-budgetary expenditures on education (endogenous } \\
\text { factor) }\end{array}$ \\
\hline ne & $\begin{array}{l}\text { The latent factor of extra-budgetary expenditures on education (endogenous } \\
\text { factor) }\end{array}$ \\
\hline DELTA, EPSILON, ZETA & Error terms and deviations \\
\hline
\end{tabular}


In SEM observed variables reflect real measured statistics over a certain period of time, while latent variables mean indicators that explain the structure of connections in the system and are not explicit. The introduction of latent variables solves the problem of the lack of uncertainty in the volume of extrabudgetary financing of the education sector in Ukraine. The proposed approach is based on maximizing the exogenous effective parameter (index of educational) in the terms of increase of endogenous factors (budget and extra-budgetary expenditures).

The software package Statistica 6.1 has a special module "Modeling by structural equations" that with a number of necessary settings automatically receive the following results of the structural simulation (Table 3).

Table 3 - Assessment of the model of interconnection of the index of education, budget and extra-budgetary expenditures on education

\begin{tabular}{|c|c|c|c|c|}
\hline & Estimation & Standard error & t-statistics & Probability \\
\hline (ie)-1->[IE] & $-0,002$ & 0,259 & $-0,009$ & 0,993 \\
\hline \multicolumn{5}{|l|}{$(\mathrm{DELTA} 1) \rightarrow[\mathrm{IE}]$} \\
\hline (DELTA1)-2-(DELTA1) & 0,826 & 0,312 & 2,646 & 0,008 \\
\hline \multicolumn{5}{|l|}{$(\mathrm{be}) \rightarrow[\mathrm{BE}]$} \\
\hline \multicolumn{5}{|l|}{$(\mathrm{ne}) \rightarrow[\mathrm{NE}]$} \\
\hline \multicolumn{5}{|l|}{$($ EPSILON1) $\rightarrow[\mathrm{BE}]$} \\
\hline \multicolumn{5}{|l|}{$($ EPSILON2) $\rightarrow[\mathrm{NE}]$} \\
\hline (EPSILON1)-3-(EPSILON1) & 629057,249 & 0,000 & & \\
\hline (EPSILON2)-4-(EPSILON2) & 0,500 & 0,000 & & \\
\hline \multicolumn{5}{|l|}{$($ ZETA1) $\rightarrow($ be $)$} \\
\hline \multicolumn{5}{|l|}{$($ ZETA2) $\rightarrow$ (ne) } \\
\hline (ZETA1)-5-(ZETA1) & 192486,179 & 126685,505 & 1,519 & 0,129 \\
\hline (ZETA2)-6-(ZETA2) & 0,500 & 0,000 & & \\
\hline (ie)-7->(be) & 2446,599 & 509,376 & 4,803 & 0,000 \\
\hline (ie)-8->(ne) & 786,132 & 0,000 & & \\
\hline (be)-9->(ne) & 0,411 & 0,071 & 5,774 & 0,000 \\
\hline
\end{tabular}

The quality of the constructed model, as well as the adequacy of its results, can be verified using the results of the iteration process, the ICSF and ICS criteria, the cosine maximum values, and the maximum modulus component of the gradient, etc. The values of these indicators indicate the adequacy of the constructed model and the significance of its parameters, which allows us to go directly to the interpretation of the data obtained a big system of equations.

$$
\left\{\begin{array}{l}
n e=786.132 i e+00.411 b e+0.5 \\
b e=2446,599 i e+192486,179 \\
B E=b e+629057,249 \\
N E=n e+0.5
\end{array}\right.
$$

This system of equations reflects the relationship between the index of education, budget and extrabudgetary funding. At the final step of solution these systems of equations (2) we can express the observed variable of extra-budgetary expenditures on education using the following system (3): 
A. Vorontsova, S. Lyeonov, T. Vasylieva, A. Artyukhov. Innovations In The Financing Of Lifelong Learning System: Expenditure Optimization Model

$$
\left\{\begin{array}{l}
N E^{*}=786.132 / E+00.411 B E-258542.05 \\
N E \%=B E /\left(N E^{*}\right) * 100 \\
N E=B E /(\overline{N E \%} / 100)
\end{array}\right.
$$

This system of equations reflects the relationship between the index of education, budget and extrabudgetary funding. At the final step of solution these systems of equations (2) we can express the observed variable of extra-budgetary expenditures on education using the following system (4):

$$
\left\{\begin{array}{l}
N E^{*}=786.132 / E+00.411 B E-258542.05 \\
N E \%=B E /\left(N E^{*}\right)^{*} 100 \\
N E=B E /(\overline{N E \%} / 100)
\end{array}\right.
$$

By substituting real data of the indicators in the last equation (3), we obtain the simulated value of the optimal amount of extra-budgetary financing of the lifelong learning system, which considers possible sources of non-state nature. The total amount of possible allocations for education from the budget and extra-budgetary sources ("a" and "b") is proposed to be interpreted as the financial potential of the lifelong learning system development (Table 4).

Table 4 - Output data for SEM

\begin{tabular}{|c|c|c|c|}
\hline Year & $\begin{array}{c}\text { Budget expenditures on } \\
\text { education (a), } \\
\text { mln. UAH }\end{array}$ & $\begin{array}{c}\text { Extra-budgetary } \\
\text { expenditures on education } \\
\text { (b), mln. UAH }\end{array}$ & $\begin{array}{c}\text { Financial potential of } \\
\text { development the LLS, }\end{array}$ \\
\hline 2002 & 12269,05 & 40859,68 & 53128,73 \\
\hline 2003 & 14977,74 & 49880,46 & 64858,20 \\
\hline 2004 & 18333,18 & 61055,11 & 79388,29 \\
\hline 2005 & 26801,75 & 89258,02 & 116059,77 \\
\hline 2006 & 33785,00 & 112514,39 & 146299,39 \\
\hline 2007 & 44333,58 & 147644,36 & 191977,94 \\
\hline 2008 & 60959,37 & 203013,35 & 263972,72 \\
\hline 2009 & 66773,56 & 222376,36 & 289149,92 \\
\hline 2010 & 79826,05 & 265845,14 & 345671,18 \\
\hline 2011 & 86253,55 & 287250,71 & 373504,27 \\
\hline 2012 & 101560,95 & 338229,01 & 439789,95 \\
\hline 2013 & 105538,70 & 351476,15 & 457014,85 \\
\hline 2014 & 100109,53 & 333395,36 & 433504,89 \\
\hline 2015 & 114188,28 & 380281,90 & 494470,18 \\
\hline 2016 & 129437,71 & 431067,14 & 560504,84 \\
\hline
\end{tabular}

The obtained results are visualized in figure 7.

The retrospective calculations carried out with the help of SEM showed that for the analyzed period of 2002-2016 in Ukraine, on average the ratio between budget and extra-budgetary expenditures on education should be about $25 \%$ to $75 \%$ that related with the index of education. In addition, the growth rate of the extra-budgetary expenditures on education far exceed the budget expenditures, which indicates the need to attract additional funding from sources other than public funds. 


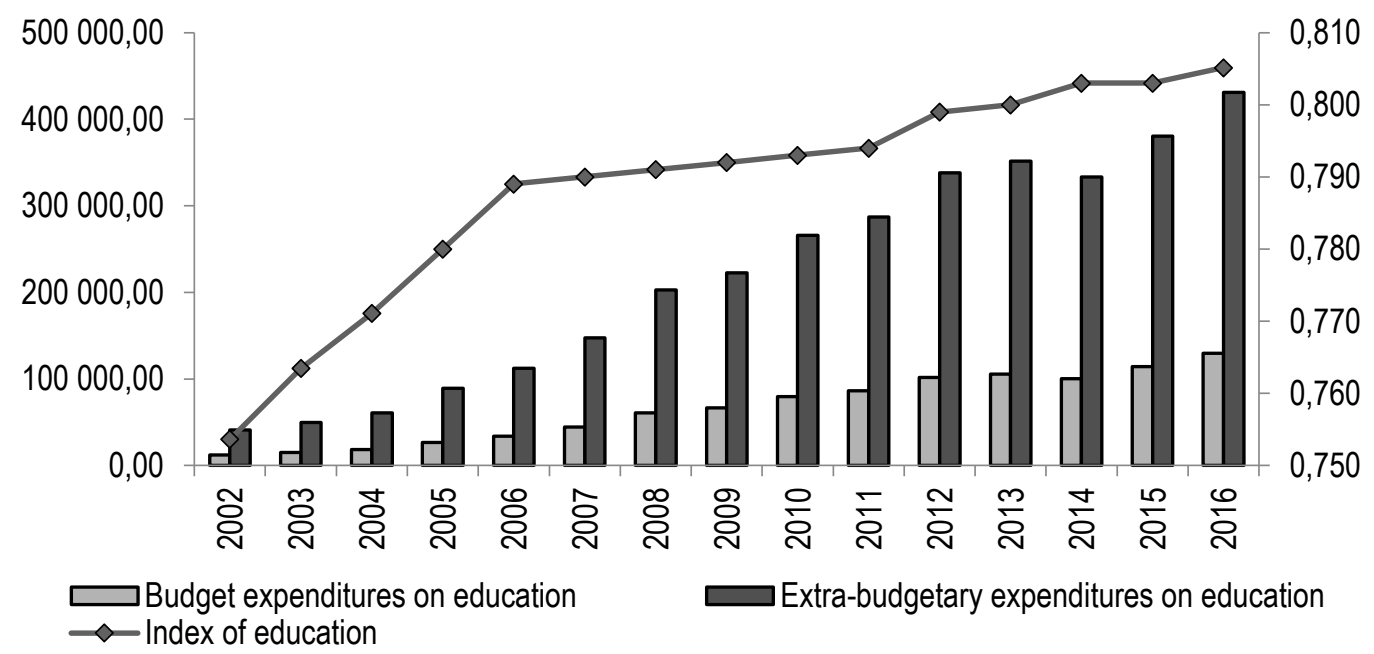

\section{Figure 7 - The ratio between budget and extra-budgetary expenditures on education, index of} education in Ukraine for 2002-2016

Conclusions. It should be noted that the issue concerning the sources which should be used to finance educational services is extremely relevant in the modern society, especially in the context of development and spread of a new lifelong learning concept. The main characteristics of LLS are the possibility to acquire the education of various forms (institutional, individual, dual), levels (preschool, secondary education, higher education, adult education, etc.), types (formal, informal, informal), in different subjects and throughout human life. This causes significant transformations in the development of both educational policy and the financial policy of the state. Also, principles of LLS are directly related with the economy transition to a sustainable growth model, because it contributes to socio-economic development in the macro and micro levels, personal development and social inclusiveness and so on.

Given that the state has limited financial resources and is not able to fully satisfy all the needs of society, it is necessary to broaden the circle of subjects and to apply mechanisms of inter-sectoral interaction. Unfortunately, official statistics of the countries of the world contain information only on the financing of formal education at different levels, while omitting non-formal education and adult education as an important component of the lifelong education system.

In this regard, in the article, methodical principles for determining lifelong learning system expenses optimization model are developed. First of all, authors propose to use SEM for calculation of potential extra-budgetary expenditures on education, taking for the basis expenditures on the education of the Consolidated Budget of Ukraine and the index of education (as a component of the index of human development). The retrospective calculations showed that for the period of 2002-2016, on average, the annual budget expenditures on education should be about $25 \%$, and extra-budgetary expenditures on education - about $75 \%$ of their total. The proposed diversified approach to the formation of the expense's optimization model is fully in line with the basic principles of the lifelong learning concept adopted by international organizations, such as UNESCO.

Acknowledgments. The survey was supported by the Ministry of Education and Science of Ukraine and performed the results of the project "Modeling and forecasting of the socio-economic-political road map of reforms in Ukraine for the transition to a sustainable growth model" (registration number 0118U003569) 
A. Vorontsova, S. Lyeonov, T. Vasylieva, A. Artyukhov. Innovations In The Financing Of Lifelong Learning System: Expenditure Optimization Model

Aspin, D. N., Chapman, J. D. (2000). Lifelong learning: concepts and conceptions. International Journal of Lifelong Education, 19(1), 2-19.

Bagmet, M., Liakhovets, O. (2017), Towards the European Union's Education Standards: Expectations of the Ukrainians, Economics and Sociology, Vol. 10, No. 2, pp. 191-206. DOI: 10.14254/2071-789X.2017/10-2/14.

Lifelong Learning in the 21st Century and Beyond. Journal of RadioGraphics. 29(2), 613-622.

Dave, R. H. (1976). Foundation of Lifelong Education: Some Methodological Aspects. Oxford: Pergamon Press.

Dave, R. H. (1976). Illustrative Content Analysis and Synthesis. Oxford: Pergamon Press.

Duyff, R. L. (1999). The value of lifelong learning: key element in professional career development. Journal of Am Diet Assoc. 99 (5), 538-543. Ishchenko-Padukova, O., Kazachanskaya, E., Movchan, I., \& Nawrot, L. (2017)

OECD (2017). Education at a Glance 2017: OECD Indicators. Paris: OECD Publishing. Retrieved from http://dx.doi.org/10.1787/eag-2017-en.

Economy of education: National and global aspects. Journal of International Studies, 10(4), 246-258. doi:10.14254/2071 8330.2017/10-4/19.

Jikia G., Vorontsova A., Petrushenko Y. (2017). Measuring Efficiency of Financial Support in Lifelong Learning System: A Case Study of Ukrainian Regions. Business Ethics and Leadership. Vol.1, Issue 4. P. 84-92. DOl: 10.21272/bel.1(4).84-92.2017.

Laal, M. (2011). Barriers to lifelong learning. Social and Behavioral Sciences. 28, 612-615.

World Bank (2003). Lifelong Learning in the Global Knowledge Economy: Challenges for Developing Countries. A World Bank Report. Washington, D.C. Retrieved from: http://siteresources.worldbank.org/INTLL/Resources/Lifelong-Learning-in-the-GlobalKnowledge-Economy/lifelonglearning_GKE.pdf.

Petrushenko, Yu. M., Vasylieva, T. A., Lyeonov, S. V., Vorontsova, A. S. (2017). Investment in the development of a system of long life education as an effective factor of socioeconomic development. Financial and credit activity: problems of theory and practice: collection of scientific works, 2(23), 426-436.

Skačkauskienè, I., Kazlauskienè, E., Katinienè, A. (2017). Modelling Knowledge Synergy Evaluation. Montenegrin Journal of Economics, Vol. 12, No. 3, 35-49.

Švagždienè, B., Jasinskas, E., Simanavičius A. (2017). The Success of Learning Organisation: Values Contextualization Dimension, Montenegrin Journal of Economics, Vol. 13, No. 4, 101-108.

Szilágyi, G. A. (2017). Exploration Knowledge Sharing Networks Using Social Network Analysis Methods. Economics and Sociology, 10(3), 179-191. doi:10.14254/2071-789X.2017/10-3/13.

UN General Assembly (2015). Transforming our world: the 2030 Agenda for Sustainable Development. Retrieved from: http://www.refworld.org/docid/57b6e3e44.html.

Tvaronavičienè, M., Tarkhanova, E., \& Durglishvili, N. (2018). Sustainable economic growth and innovative development of educational systems. Journal of International Studies, 11(1), 248-256. doi:10.14254/2071-8330.2018/11-1/19.

Vardanyan, N. (2017). Education Quality Assessment from the Perspective of Stakeholders on the Example of Armenian Higher Education Institutions. Business Ethics and Leadership, 1(3), 93-97. DOI: 10.21272/bel.1(3).93-97.2017

Vasilyeva, T., Lyeonov, S., Adamičková, I., Bagmet, K. (2018). Institutional Quality of Social Sector: the Essence and Measurements. Economics and Sociology, 11(2), 248-262. doi:10.14254/2071-789X.2018/11-2/17.

Vasylieva, T., Lyeonov, S., Vorontsova, A. (2018). Management of education in the context of its financial support as a publicprivate good. Annals of Marketing Management \& Economics. Vol. 4, No 1. P. 163-173.

OECD (2017). Who really bears the cost of education? How the burden of education expenditure shifts from the public to the private sector. Education Indicators in Focus. 56. Paris: OECD Publishing. Retrieved from: http://dx.doi.org/10.1787/4c4f545b-en.

Kozmenko, O. V., Kuzmenko, O. V. (2014). Ekonomiko-matematyčni metody ta modeli (ekonometryka) (Economicmathematical methods and models (econometrics)): a manual. Sumy: Universytetska knyga.

Ukrainian State Statistics Service (2015). National Accounts of Education of Ukraine. Statistical Bulletin

Shevchenko, L. S. (2013). Bezperervnist' jak osnovnyj pryncyp reformuvannja sučasnoji systemy osvity (Continuity as the main principle of reforming the modern education system). Socio-economic transformations of the modern world: scientific-practical conference materials. Kharkiv: National University Jaroslav Mudriy Law Academy of Ukraine, 83-86.

A. С. Воронцова, к.е.н., Сумський державний університет (Суми, Україна);

C. В. Лєонов, д.е.н., професор, Сумський державний університет (Суми, Україна);

T. A. Васильєва, д.е.н., професор, Сумський державний університет (Суми, Україна);

A. Є. Артюхов, к.т.н., доцент, Сумський державний університет (Суми, Україна).

Інновації в системі фінансування освіти впродовж усього життя: модель оптимізації витрат

В останні роки в більшості країн світу все активніше спостерігається впровадження освітніх інновацій, поширення та зміна основної парадигми системи освіти, що передбачає доповнення класичної формальної освіти (тобто, ө офріційних навчальних закладах з отриманням відповідного документу офріційного зразку) неформальною та інформальною. Особливості останніх двох форм освіти полягають в отриманні людиною знань, навичок та здібностей для ії̈ всебічного розвитку та підвищення кваліфікації, формування громадянської позиції та мотивації до саморозвитку і самонавчання, без обов'язкового супроводження офіційно-визнаним документами, що при цьому не зменшує їх цінність. 
Це зумовлює формування нового типу освіти - освіти впродовж усього життя людини, а формування ефективних систем організації такого типу освіти повинно стати одним із стратегічних завдань для будь-якої держави, що прагне до сталого розвитку. Такі зміни вимагають інноваційного підходу на всіх етапах становлення нової системи, у тому числі в ії фрінансовому забезпеченні. Проте в силу об'єктивної обмеженості бюджетних коштів, держава не може самостійно забезпечувати фінансування системи освіти впродовж усього життя без залучення додаткових ресурсів від інших суб'єктів економіки. Таким чином, метою даної статmі є розроблення інноваційної моделі оптимізації витрат в системі освіти впродовж усього життя. Підгрунтям для цього став проведений авторами аналіз сутності та основних характеристик системи освіти впродовж усього життя в різних країнах світу. Також проведено порівняльний аналіз основних тенденцій фінансування освіти в країнах Організації економічного співробітництва та розвитку (OECP) та їхніх партнерів, а також України за рахунок різних джерел (державних та приватних) та для різних рівнів освіти (початкова освіта, середня освіта, післядипломна освіта, незакінчена вища освіта, вища освіта). За результатами аналізу було виявлено відсутність структурованої інформації щодо позабюджетного фрінансування системи безперервної освіти. Таким чином, авторами було розроблено інноваційний підхід до визначення потенційного обсягу позабюджетних джерел фрінансування системи безперервної освіти за допомогою методу моделювання структурних рівнянь, де за базу розрахунку прийнято видатки на освіту Зведеного бюджету України й індекс освіти (як складова індексу людського розвитку). Для моделювання використано програмний продукт STATISTICA 6.1. Цей підхід дозволяе сформувати модель оптимізації витрат та визначити фрінансовий потенціал розвитку системи освіти впродовж усього життя.

Ключові слова: фінансова підтримка, система безперервної освіти, державні витрати, приватні витрати, модель оптимізації витрат, структуроване моделювання. 